Indonesian Journal of EFL and Linguistics

Vol. 5 No. 2, 2020

eISSN: 2503-4197, pISSN: 2527-5070

www. indonesian-efl-journal.org

\title{
Exploring the Students' Response of Flipped Learning through Social Networking Sites (SNSs)
}

\author{
Lutvy Arsanti \\ Agus Wijayanto \\ Suparno \\ Department of English Education \\ Universitas Sebelas Maret, Indonesia \\ e-mail: lutvy.arsanti@student.uns.ac.id
}

\begin{abstract}
:
Flipped learning has developed a particular approach that facilitates the students to acquire new knowledge outside the classroom. In this digital era, it grows as technology does. MALL (Mobile Assisted Language Learning) has a vital role in supporting English language teaching implementation. It has several applications, which can be a tool to teach English. One of the applications is using Social Networking Sites (SNSs), which the students have a high interest in using it in daily life. The research is a case study that aims to investigate the students' perception of flipped learning through Social Networking Sites (SNSs) to develop their writing ability. The participants of the research are 30 English department students in the second semester. There are ten men and 20 women in the class. The data collection was from an interview and a Technology Acceptance Model (TAM) questionnaire. This research indicates that the students have more ideas to write, and they can collaborate with their friends in writing through Social Networking Sites (SNSs). The result shows that the flipped classroom's implementation through SNSs is an alternative way for teachers to facilitate the learning of EFL writing in this digital era.

Keywords: flipped classroom, Social Networking Sites (SNSS), students' perception, writing ability
\end{abstract}

Indonesian Journal of EFL and Linguistics, 5(2), 2020 


\section{INTRODUCTION}

Innovative teachers need to practice educational methods to improve learning and inspire students (Johnson et. al., 2014). Flipped learning has been developed as a unique method that contradicts the application of assignment and in-class activities. In classical education, students discover new knowledge in the classroom through lectures, and the professor asks them to study what they have learned by assigning tasks.

In contrast, flipped learning provides new knowledge to students at home. For example, they can watch the video shared by the teacher and have a chance to practice it in the classroom. When the students practiced what they have already learned at home, the teacher can monitor and give the students feedback.

Flipped learning collaborates with technology for outside class learning (Herrald \& Schiller, 2013). In this digital era, the teachers developed and combined it with technology. The use of technology is not the tool in the learning process, but it supports education, especially language learning. Social networking sites (SNSs) have the potential to affect language teaching (Godwin-jones, 2010). There are some previous studies (Amer, 2014; Chen \& Hsieh, 2008; Kiernan \& Aizawa, 2013; Stockwell \& Hubbard, 2013) that investigate the aids of Mobile Assisted Language Learning (MALL). The studies conducted are in English language teaching (Kukulskahulme, 2009; Saran \& Seferoğlu, 2010; Stockwell \& Hubbard, 2013).

According to several previous studies, there are numerous researches studied about the effectiveness of flipped learning and mobile technology in English learning. The analysis indicated that digital learning in enhancing students' motivation to learn and participate (Murdock \& Williams, 2011; Scott et al., 2017; Norbrook \& Scott, 2003) because of the accessibility, portability, interactivity, and immediacy of mobile devices. On the other hand, there is limited research investigating students' perception of flipped learning through social networking sites (SNSs). This research filled the gap by examining the students' perception of flipped learning through social networking sites (SNSs) in developing students' writing ability.

Therefore, the research objective was to explore the students' perceptions of the flipped classroom through social networking sites (SNSs) to improve students' writing skills. Accordingly, the researcher conducted this research by employing a Technology Acceptance Model (TAM) questionnaire. Furthermore, the questionnaire contains several questions to determine how students think about the usefulness, use, material characteristics, system characteristics, and behavioral intention in flipped learning through SNSs. To answer this goal and purpose, the writer formulated the following questions:

1. What is the students' perception of flipped classroom learning in SNSs?

2. What are the benefits and the challenges experienced by the students in flipped learning through SNS? 


\section{LITERATURE REVIEW \\ 2.1 Flipped Classroom}

A flipped classroom is a teaching strategy which changes the class duration by focusing on the students' self learning and allocates the face-to-face class to have a discussion and communication between the students and the teachers (Bergmann \& Sams, 2014). Increasing students' participation, the strategy has become successful in providing students to achieve higher language proficiency (Bretzmann et al., 2013). In flipped classrooms, technology has the primary objective in allocating the class time to increase the students' improvement in L2. The additional time help the students to enhance their ability to get the more level of cognitive skill.

The cognitive load theory which explained that the success ful flipped classroom depends on the students' ability to achieve the lower level of cognitive load (receiving and understanding information) outside the class (Sweller, 1988). Moreover, the students needed to focus on high level of cognitive load (application, analysis , synthesis, or evaluation) within the face-to-face classroom. As a result, 80 per cent of students in flipped classrooms spent more time and energy gaining and processing new information on their own pace. Flipped classroom made them more involved in the learning process (Hung, 2015).

Although flipped classrooms are important to conduct an online pre-class learning, they are more than just providing videos and screencasts (Bergmann \& Sams, 2014). Giving introduction of digital technologies, the world has become more interactive because of the use of internet and smartphone. Previous studies stated that many mobile applications had many impacts to succeed the language learning. Technology Acceptance Model (TAM) is a reliable instrument for analyzing the attitudes of language learners on technological acceptance (Lee, Hsiao, \& Purnomo, 2014). Moreover, there were some research of flipped classroom in English skills. Mubarok et. al. (2019) stated that flipped classroom model provided more improvement in learning English writing than the traditional teaching. Based on the scores of pre and post test, there was significant improvement of the experimental class after experiencing flipped classroom. Pudin (2017) conducted a research of flipped classroom in grammar class. The finding was that mostly students were enthusiastic to learn grammar through flipped classroom than traditional grammar classroom.

\subsection{Social Networking Sites (SNSs) and EFL Learning}

The study states that social networking sites (SNSs) can encourage EFL learning, mainly when the aim is to promote valuable learners' communication and interaction. Vie (2007) says that SNSs provide EFL learners a way to socialize to make the learners are encouraged to use language for social aim. Furthermore, SNSs give a way to utilize language for socialization and communication (McBride, 2008). The effect of SNSs is to urge communication can also influence on learners' collaboration. SNSs named "Ning" improve group collaboration and peer feedback, which showed improved learner collaboration (Toetenel, 2014). 
SNSs have three types as a way to support the language learning context (Lomicka \& Lord, 2009) : 1) provide the chances to engage in written discourse (for example Facebook, Linkedin or Twitter); 2) emphasize mostly on spoken discourse (for instance PodOmatic, VoiceThread or video messaging sites); 3) focus on posting images (for example Instagram, Pinterest or Snapchat). According to the first type of SNSs, there is no more in-depth study on the implementation of LinkedIn for language learning. Some studies note Twitter's potential as a learning tool that can be implemented in teaching writing skills, and FB performs to be the most studied SNSs, mostly emphasizing Higher Education and enhancing writing skills. According to the second type of SNSs, some studies on the application of Skype, Podcasts, and VoiceThread to improve oral skills were recorded. Based on the third type of SNSs, some studies found that Instagram's potential to develop speaking skills (such as recording and watching short speaking tasks) is "prompt" for giving the writing tasks and improving vocabulary. In contrast, there is no wide-ranging study on implementing either Pinterest or Snapchat in language learning.

SNS can be useful in the area focus on (1) the motivational benefits of SNSs, and their affordances for (2) observation of and participation in genuine L2 sociopragmatic practice, (3) situated and simulated way, (4) literacies development, and (5) autonomous learning. Based on the characteristics of SNSs, it is applicable to be implemented in any subject's learning process (Reinhardt, 2019). Moreover, SNS is beneficial in language learning because it facilitates a communicative situation to encourage and interact with the target language. SNSs facilitate a language communication/ interaction which teachers essentially attempt in a language teaching. A challenge for the teachers is using social media to improve the learning process and develop the learning outcomes.

Wang and Vasquez (2014) stated, “...more observed research is required - especially research designs which employ a comparison or control group - to examine the effectiveness of using SNSs on facilitating different domains of language learning" ( $\mathrm{p}$. 102). There is only limited research using SNSs in EFL learning, although many SNSs occur in this digital era. SNS, commonly used in people's daily lives, is Facebook, Instagram, Twitter, Line, and many others. Instagram is one of the SNS which becomes popular in young people's everyday life. The study would investigate how students' perception of flipped learning through Instagram is used in flipped learning, especially in developing students' writing ability.

\section{RESEARCH METHODOLOGY}

The current research was carried out in an academic writing class at a university in Indonesia. The lecturer facilitated the students with flipped learning through social networking sites. The present study aimed to investigate the students' perception of flipped learning through a social networking site (SNS). The researcher has conducted a descriptive case study research. A case study is on a present phenomenon within a real-life framework (Yin, 2017). In the study, the participants were 30 students from the English Education Department. There are ten men and 20 women. The writer used 
purposive sampling to select the participants for this study. The research was done in a month.

There are different social networking sites, but the current study employed Instagram as a teaching tool. In this research, Instagram decided to use its advantages as a writing tool. The use of technology devices in previous studies has positively impacted language classrooms, especially in HE universities (Ekoç, 2014). As Instagram improves both descriptive languages, cultural awareness, and competence, it is expected that it will inspire students to practice both formal and informal English writing (Lomicka \& Lord, 2009).

Since students learned English through flipped learning on social media platforms, they got a questionnaire in Google form. The questionnaire was distributed to examine students ' perceptions of the use of SNSs in flipped learning. The questionnaire used is the Technology Acceptance Model (TAM). The study adopted the Technology Adoption Model (TAM) developed by Davis and co-workers (Davis, 1989; Davis et al., 1989). Statements have been adjusted to reflect participants' overall viewpoints on the use of Instagram in the course using the Likert 5-point scale.

Administering a TAM questionnaire, the researcher interviewed some students to get more data. After getting the result of the questionnaire, the data were analyzed by using three stages. They were data reduction, data display, and data verification. After elaborating on the TAM questionnaire result, the researcher gave more additional data from the interview result with the students. Before interviewing with six students, the writer prepared some questions of the interview. Several items were given to explore their opinion about the learning experiences using flipped learning through Instagram, the reasons they like/dislike to use SNS, and the challenges they feel while doing flipped learning in SNS.

\section{FINDINGS}

\section{Students' perception of flipped learning through social networking site (SNS)}

Table 1 The Percentage of Students' Perceptions of Flipped Learning through Instagram based on System Characteristic Criteria

\begin{tabular}{lc}
\hline \multicolumn{1}{c}{ System Characteristics } \\
\hline \multicolumn{1}{c}{ Indicator } & Percentage \\
Based on the questionnaire result, the students agree that & $88,9 \%$ \\
using Instagram provided a stimulating English learning \\
environment.
\end{tabular}

Indonesian Journal of EFL and Linguistics, 5(2), 2020 
The majority of the students $(88.9 \%)$ accepted on using Instagram with a stimulating English learning setting. Also 62.3 per cent of students can successfully use Instagram to communicate with teachers and their peers to learn English. In addition, 72.2 percent of students feel more comfortable using Instagram to comment on the content posted by their peers compared to face-to - face comments.

\begin{tabular}{|c|c|}
\hline \multicolumn{2}{|l|}{ Material Characteristics } \\
\hline Indicator & Percentage \\
\hline $\begin{array}{l}\text { The pictures/video materials made by the lecturer led } \\
\text { to be a better understanding of EFL writing }\end{array}$ & $80 \%$ \\
\hline $\begin{array}{l}\text { The images/video materials created by the lecturer } \\
\text { helped me immerse myself in the learning } \\
\text { atmosphere of the class. }\end{array}$ & $83,9 \%$ \\
\hline $\begin{array}{l}\text { The pictures/video materials made by the lecturer } \\
\text { were useful to practice writing in Instagram }\end{array}$ & $80,7 \%$ \\
\hline $\begin{array}{l}\text { The images/video materials created by the lecturer } \\
\text { encouraged me to write through Instagram }\end{array}$ & $70,9 \%$ \\
\hline
\end{tabular}

A majority of the participants (80 percent) agreed that pictures/video materials created by the lecturer led to be a better understanding of EFL writing. They also decided that the lecturer's pictures/video materials helped them immerse themselves in the class's learning atmosphere. Furthermore, the photo and video allowed them to practice English writing and encourage them to develop their writing skills through social networking sites (SNSs).

\section{Table 3 The Percentage of Students' Perceptions of Flipped Learning through} Instagram based on Perceived Ease of Use Criteria

\begin{tabular}{lc}
\hline \multicolumn{2}{c}{ Perceived Ease of Use } \\
\hline \multicolumn{1}{c}{ Indicator } & Percentage \\
$\begin{array}{l}\text { I received clear guidance and instruction about my } \\
\text { homework via Instagram }\end{array}$ & $65,78 \%$ \\
Using Instagram did not require too much time & $80,5 \%$ \\
Learning to use Instagram for my class activities was & $75,4 \%$ \\
easy & $60 \%$ \\
$\begin{array}{l}\text { Interacting with my lecturer and peers through } \\
\text { Instagram was convenient and not stressful }\end{array}$ \\
\hline
\end{tabular}

Based on the perceived ease of use, the student had clear enough explanation about how to do the task through social networking sites (Instagram). Moreover, they agreed that Instagram was applicable and flexible to be used in practicing English writing. It 
is proven by 80,5 percent of students who had answered the questionnaire. Its easiness made the students could easily practice the writing task every time and everywhere.

\section{Table 4 The Percentage of Students' Perceptions of Flipped Learning through Instagram based on Attitude about Use Criteria}

\begin{tabular}{lc}
\hline \multicolumn{1}{c}{ Attitude about Use } \\
\hline \multicolumn{1}{c}{ Indicator } & Percentage \\
\hline $\begin{array}{l}\text { I like using Instagram to learn English, especially } \\
\text { EFL writing. }\end{array}$ & $82,3 \%$ \\
$\begin{array}{l}\text { I have a positive attitude about using Instagram in } \\
\text { the class. }\end{array}$ & $90,5 \%$ \\
$\begin{array}{l}\text { I feel that using Instagram to learn English is a good } \\
\text { idea. }\end{array}$ & $78,4 \%$ \\
$\quad$ I look forward to using Instagram in this class. & $70 \%$ \\
\hline
\end{tabular}

Based on the result of the attitude about use criteria, most students enjoy using Instagram to learn English, especially in writing (82,2 percent). They enjoyed the process of doing writing through Instagram. The students had a positive attitude of EFL writing through Instagram. Practicality was the most important thing that Instagram could provide to support EFL writing.

\section{Table 5 The Percentage of Students' Perceptions of Flipped Learning through} Instagram based on Attitude about Behavioral Intention Criteria

\begin{tabular}{lc}
\hline \multicolumn{1}{c}{ Behavioral Intention } \\
\hline \multicolumn{1}{c}{ Indicator } & Percentage \\
\hline \multicolumn{1}{c}{ If I have access to Instagram, I will continue to write } & $82,3 \%$ \\
English sentences with my own language. & \\
$\begin{array}{l}\text { If I have access to Instagram, I will continue to use it } \\
\text { to have peer feedback with my peer by commenting } \\
\text { on Instagram. }\end{array}$ & $80,6 \%$ \\
$\begin{array}{l}\text { If I have access to Instagram, I will be happy to } \\
\text { practice writing more and more. }\end{array}$ & $69,7 \%$ \\
$\begin{array}{l}\text { When I use Instagram to practice my writing, I am } \\
\text { not afraid of making mistakes }\end{array}$ & $68 \%$ \\
\hline
\end{tabular}

The result of students' perception of behavioral criteria is high. The students agreed that they used their language to create English sentences through social networking sites (Instagram). For them, social networking sites provided a place to take and give feedback to other students' writing. On the other hand, the students' answer to being afraid of making mistakes was high enough (68 percent). It was a problem that could be analyzed more in the discussion. 
Lutvy Arsanti, Agus Wijayanto, Suparno

\section{DISCUSSION}

\subsection{Benefits of using Social Networking Sites (SNSs) as a mobile tool for language learning}

The students' perception of flipped learning through a social networking site (SNS) practice in writing class is explained based on the result of the interview and questionnaire. The interview is conducted to gain the students' opinions toward implementing flipped learning through a social networking site. The technological acceptance model questionnaire with a Likert scale was administered to support the data. In the questionnaire, several statements about the system characteristics, material characteristics, perceived ease of use, perceived usefulness, attitude about usage, and behavioral intention.

The implementation of flipped learning through social networking sites was done in 4 meetings. The lecturer conducted it in the writing class. Based on the sub-question of system characteristics, the result shows that the students feel more enjoyable in interacting with their peers to practice EFL writing. Social networking sites (SNSs) can affect language learning (Godwin-jones, 2010; Blattner \& Fiori, 2009; GodwinJones, 2010). The potential of SNS is to provide an easy way to practice writing. Students answer that they like to write their comments using English sentences. Once they made mistakes, the peer would correct them. It made them not only learn to form a proper sentence but also to know how to fix the errors by themselves. Furthermore, they think that practicing EFL writing through social networking sites is more accessible than face to face techniques.

"Do you enjoy flipped learning through social networking sites (SNS)?"

"Yes, I think it is interesting. My lecturer usually gets angry if I use my cell phone in the class, but now I can use it in the learning process, I can do my task with my social media."

"I like to use Instagram to write my caption because I think it is cool to make a good English caption. I feel more confident,".

"It is good to practice writing in ig. I can do it everywhere. I am bored when my lecturer usually uses the teacher-talk technique while I'm studying English."

"I can interact with my friends without the need to have a study group. It is effortless, I can do my writing fast."

Based on the first issue, students' experience of flipped learning through Instagram is both positive and realistic. Several students accepted that education could develop writing skills more because the SNS had them communicate. It also offers practicality in the writing of the EFL. This present study has the same result which stated that the students felt more encouraged in team work and enhanced their interaction (Pudin, 2017) . In this research, teacher-student interactions on social media 
outside school hours may help to reduce the difference between formal and informal learning faced by many university students (Reinhardt \& Ryu, 2013).

Second, based on the sub-question material characteristics, the result shows that the materials made by the lectures give them more understanding of EFL writing. Furthermore, $48 \%$ of the answer is that the students immerse themselves in the class's learning atmosphere. It means that they enjoy the flipped learning through social networking sites. Then, the materials are interesting to brainstorm some ideas to write. There are four principal dimensions of a learner's experience with Web 2.0: collaboration, the publication (both social), literacy, and inquiry (cognitive) (Lomicka $\&$ Lord, 2009). The publication dimension lets the students work to a broader audience and display of classroom activities. Students may "publish and argue the results of their study" in an "unbounded space." The ideas to write can be taken outside the class, SNS let the students discuss it in out-bounded space.

"Why do you like to do the task through SNS?"

"Of course, because of its easiness, we can do the task anywhere. Furthermore, it does not need more time; it is fast. I can also learn from some materials uploaded by my lecture through Instagram."

Third, the easy-to-use outcome is that students have a simple understanding of flipped learning across social networking sites. Students do not need more time to do the task because SNS can be accessed anytime and anywhere. It makes it simpler and better to train.The finding is matched that the students can access the materials easily due to the flexibility to access it using SNS (Mubarok et al., 2019). Most of them think that flipped learning by SNS gives their peers a fast response to get input from their peers quickly. Besides, students agree that feedback and suggestions from both the instructor and peers will motivate them to practice EFL writing. Both reviews and feedback are required to improve their ability to write. Accordingly, the students could pass their maximum learning potential that was in line with the previous research (Afrilyasanti et al., 2017).

Based on students' attitudes and behavioral intention of flipped learning through SNS, it is concluded that they are encouraged by experiencing it. They feel enthusiastic about practicing if they have access to the SNS in the class. The students' perception of flipped learning's usefulness by using SNS is the same as the related study. The study was conducted by using the other SNS, which is a telegram. The students agreed that the flipped classroom's implementation via telegram helped and encouraged them in the ELT class (Haghighi et al., 2018). The students are not afraid of making mistakes when they write on the SNS. It is slightly different in the class that they are so shy and feel discouraged to show their writing. The anxiety of making mistakes is more significant when the students are chosen to write in front of the class. In contrast, the students have the freedom to share their opinion about everything they had in their minds through flipped learning in social networking sites. 
The outcome of the Technology Acceptance Model (TAM) questionnaire showed that the learners consider Instagram as a medium that promotes an inspiring and essential English learning environment. The present study was in line with a research from Akhiar et al. (2017). He argued that Instagram, as a social media organization, can deliver a less-threatening learning atmosphere compared to conventional environments, create more spaces for collaborative learning activities, and successively increase the chances of further engagement. Moreover, a research conducted by Pudin (2017) stated that most of the students agree that social media is important for not only socializing but also for learning. The study's finding was matched with a research which used the LINE application as an online teaching tool for the ELT (Wu et al., 2017). The present study found that the perception of acceptance of some TAM elements was higher. It may be related to the overwhelming popularity of Instagram for Indonesian college students and the wide variety of materials used in this research.

\subsection{Challenges in using Social Networking Sites (SNSs) as a mobile tool for language learning}

Students have faced some difficulties when doing flipped learning via Instagram. First of all, some students feel nervous about making grammatical errors. They were worried that they would be blamed for their bad grammar or for making mistakes. Several students recognized that their writing output could have an effect on their social media trust, particularly when the Instagram communities read it. They said it was difficult to recognize their mistakes and to complete their online writing assignments. It is in line with Lomicka \& Lord's statement (2009) that Instagram not only emphasizes the sharing of images, but also has the potential to be a languagebased device. Some students also answered that they could not understand the explanation in the video. It is in line with the result of a research by Pudin (2017).

Social networking issues in language learning are additional activities for teachers who need to track language skills and content suitability (Shih, 2011, 2013). The potential of students to execute fake language productions in the online world (Kabilan, Ahmad, \& Abidin, 2010) and privacy issues (Gettman \& Abidin, 2010; Gettman \& Cortijo, 2015; Teclehaimanot \& Hickman, 2011). Although social media is important to interact and browse the English learning provided by the teacher, but there is a privacy problem experience by them. The finding is the same with the resulf of a research that stated that not all students keen to participate (Pudin, 2017).

"Why do you feel afraid of practicing to write on Instagram?"

"I am lack confident to write in English and let others read it." "I might get marked by others for having bad grammar, vocabulary, or other things related to language."

"I use Instagram as my branding; I am shy to share my task there. That is not cool."

Privacy is the second and most critical issue of social media. The students were not pleased to share photos and posts with strangers. They're just trying to get in touch 
with the people they know. Usually, they have changed their Instagram settings to private so that their messages are not visible to anyone. They felt the need to be careful with their gestures, because people might confuse their intentions. A few students said they did not want their teachers to know what they were doing online, a result that was similarly expressed by the participants (Teclehaimanot \& Hickman, 2011). Some students were disturbed by the presence of their faculty in their private Facebook space. Two students were of the opinion that Instagram should remain social. Some students therefore chose to create new accounts for their educational activities.

"Need privacy, and other students can copy us assignments if we post them on social media."

"Teachers may stalk us, and we have to be careful about what we want to express it."

"The challenge is that I open my personal life to strangers.It is terrible for me because I usually only accept a friend request from the close ones."

The students and the lecturers experience the challenges of using flipped learning through social networking sites. The lecturer said that she might have an extra effort to control the class. It was because the lecturer needed to check students' understanding of the instruction in doing flipped learning. It is in line with a research that the teacher needs extra tasks for teachers who have to monitor the suitability of language and content (Ansori \& Nafi', 2018).

\section{CONCLUSION}

The results showed that the students had positive perceptions after experiencing flipped learning through social networking sites (SNS) in EFL writing. The students were encouraged to write freely through SNS than to write in a paper. Moreover, they were enthusiastic about getting some corrections from their peers in the comment column through SNS. Social networking sites perceived the ease of use, usefulness, and material characteristics. Some students lack the confidence to write any idea in EFL writing, so they enjoy the flipped learning through SNS. The difficulties arise when the students feel confused about correcting their peer's mistakes in writing through SNS. The lecturer needs to discuss and correct their errors in the class. By giving feedback, the students can learn how to write and form a correct sentence before they fix them. Accordingly, the students' perception of flipped learning in social networking sites (SNS) is positive. It can be an alternative way to practice writing by flipping learning through social networking sites because the students can practice every time and everywhere.

\section{REFERENCES}

Afrilyasanti, R., Cahyono, B. Y., \& Astuti, U. P. (2017). Indonesian EFL Students' Perceptions on the Implementation of Flipped Classroom Model. Journal of Language Teaching and Research, 8(3), 476.

Indonesian Journal of EFL and Linguistics, 5(2), 2020 
Lutvy Arsanti, Agus Wijayanto, Suparno

https://doi.org/10.17507/jltr.0803.05

Akhiar, A., Mydin, A.-A., Akma, S., \& Kasuma, A. (2017). Students' Perceptions and Attitudes towards the Use ofInstagram in English Language Writing. Malaysian Journal of Learning and Instruction (MJLI), Special issue on Graduate Students Research on Education, 47-72.

Amer, M. (2014). Language learners' usage of a mobile learning application for learning idioms and collocations. CALICO Journal, 31(3), 285-302. https://doi.org/10.11139/cj.31.3.285-302

Ansori, M., \& Nafi', N. N. (2018). English Teachers' Perceived Benefits And Challenges Of Flipped Classroom Implementation. Jeels, 5(2), 211-227.

Bergmann, J., \& Sams, A. (2014). Brock international prize in education 2014 Brock International Prize in Education Nominee Our Story: Creating the Flipped Classroom. $\quad$ https://brockprize.org/wp-content/uploads/2017/08/BergmannSams.pdf

Blattner, G., \& Fiori, M. (2009). Facebook in the language classroom: Promises and possibilities. International Journal of Instructional Technology and Distance Learning, 6(1), 17-28. Retrieved from http://www.itdl.org/journal/ jan_09/article02.htm

Bretzmann, J., Bennett, B., \& Witten, H. (2013). Flipping 2.0 - Practical Strategies for Flipping Your Class. Jason Bretzman. file:///C:/Users/youhe/Downloads/kdoc_o_00042_01.pdf

Chen, N., \& Hsieh, S. (2008). Effects Of Short-Term Memory And Content. Language Learning \& Technology. 12(3), 93-113.

Davis, F. D. (1989). Perceived usefulness, perceived ease of use, and user acceptance of information technology. MIS Quarterly: Management Information Systems, 13(3), 319-339. https://doi.org/10.2307/249008

Davis, F. D., Bagozzi, R. P., \& Warshaw, P. R. (1989). User Acceptance of Computer Technology: A Comparison of Two Theoretical Models. Management Science, 35(8), 982-1003. https://doi.org/10.1287/mnsc.35.8.982

Ekoç, A. (2014). Facebook groups as a supporting tool for language classrooms. Turkish Online Journal of Distance Education, 15(3), 18-26. https://doi.org/10.17718/tojde.13403

Gettman, H. J., \& Cortijo, V. (2015). “ Leave Me and My Facebook Alone !” Understandingcollege students' relationship with facebook and its use for academic purposes. International Journal for the Scholarship of Teaching and Learning Article, 9(1), Article 8. Retrieved from http://digitalcommons. georgiasouthern.edu/ij-sotl/vol9/iss $1 / 8$

Godwin-jones, R. (2010). Emerging Technologies Literacies And Technologies Revisited. 14(3), 2-9.

Haghighi, H., Jafarigohar, M., \& Khoshsima, H. (2018). Impact of flipped classroom on EFL learners ' appropriate use of refusal: achievement, participation , perception. Computer Assisted Language Learning, O(0), 1-33. https://doi.org/10.1080/09588221.2018.1504083 
Herrald, C.F., \& Schiller, N.A. (2013). Case studies and the flipped classroom. Journal of College Science Teaching, 42 (5), 62-66.

Hung, H. (2015). Flipping the classroom for English language learners to foster active learning. Computer Assisted Language Learning, 28(1), 81-96. https://doi.org/10.1080/09588221.2014.967701

Johnson, L., Adams Becker, S., Estrada, V., \& Freeman, A. (2014). NMC horizon report: 2014 K-12 edition. Austin, TX: The New Media Consortium.

Kiernan, P. J., \& Aizawa, K. (2013). Cell phones in task based learning - Are cell phones useful language learning tools? June 2004. https://doi.org/10.1017/S0958344004000618

Kukulska-hulme, A. (2009). Open Research Online. https://doi.org/10.1017/S0958344009000202

Lomicka, L., \& Lord, G. (2009). Introduction to Social Networking , Collaboration, and Web 2 .0 Tools. In The next generation: Social networks and online collaboration in foreign language learning (pp. 1-12).

McBride, K. (2008). Social-networking sites in foreign language classes: Opportunities for re-creation. The next Generation: Social Networking and Online Collaboration in Foreign Language Learning (CALICO Monograph Series), 3558.

Mubarok, A. F., Cahyono, B. Y., \& Astuti, U. P. (2019). Effect of Flipped Classroom on Indonesian EFL. Dinamika Ilmu, 4(5), 65-81.

Murdock, J. L., \& Williams, A. M. (2011). Creating an Online Learning Community: Is it Possible? Innovative Higher Education, 36(5), 305-315. https://doi.org/10.1007/s10755-011-9188-6

Norbrook, H., \& Scott, P. (2003). Motivation in mobile modern foreign language learning. In J. Attewell, G.D. Bormida, M. Sharples \& C. Savill-Smith (Eds.), MLEARN: Learning with mobile devices (pp. 50-51). London: Learning and Skills Development Agency.

Pudin, C. S. J. (2017). Exploring a Flipped Learning Approach in Teaching Grammar for ESL Students. IJELTAL (Indonesian Journal of English Language Teaching and Applied Linguistics), 2(1), 51. https://doi.org/10.21093/ijeltal.v2i1.47

Reinhardt, J. (2019). Social media in second and foreign language teaching and learning: Blogs, wikis, and social networking. Language Teaching, 52(1), 1-39. https://doi.org/10.1017/S0261444818000356

Reinhardt, J., \& Ryu, J. (2013). Using social network-mediated bridging activities to develop socio-pragmatic awareness in elementary Korean. International Journal of Computer- Assisted Language Learning and Teaching, 3(3), 18-33. https://doi.org/10.4018/ijcallt.2013070102

Saran, M., \& Seferoğlu, G. (2010). Supporting foreign language vocabulary learning through multimedia messages via mobile phones. Hacettepe Egitim Dergisi, 38, 252-266.

Scott, J., Hsieh, C., Wu, W. V., Marek, M. W., Scott, J., Hsieh, C., Wu, W. V., \& Using, M. W. M. (2017). Using the flipped classroom to enhance EFL learning. 
Lutvy Arsanti, Agus Wijayanto, Suparno

Computer Assisted Language Learning, 30(1-2), 1-21. https://doi.org/10.1080/09588221.2015.1111910

Stockwell, G. (2010). Using mobile phones for vocabulary activities: Examining the effect of the platform. Language Learning \& Technology, 14(2), 95-110. Retrieved from http://llt.msu.edu/vol14num2/stockwell.pdf

Stockwell, G., \& Hubbard, P. (2013). Some Emerging Principles for Mobile-assisted Language Learning. The International Research Foundation for English Language Education, 2013, 1-15. https://doi.org/10.5539/ijel.v3n1p19

Sweller, J. (1988). Cognitive Load During Problem Solving : Effects on Learning. 285, 257-285.

Teclehaimanot, B., \& Hickman, T. (2011). Student-Teacher Interaction on Facebook: What Students Find Appropriate. TechTrends, 55(3), 19-30. https://doi.org/10.1007/s11528-011-0494-8

Toetenel, L. (2014). Social networking: a collaborative open educational resource. $C$ Computer Assisted Language Learning, 27:2, 149-162, DOI: 10.1080/09588221.2013.818561

Vie, S.E. (2007). Engaging others in online social networking sites: Rhetorical practices in MySpace and Facebook (Unpublished doctoral dissertation). University of Arizona, Tucson, AZ. (UMI No. 3254886)

Wang, S., \& Vasquez, C. (2014). The effect of target language use in social media on intermediate-level Chinese language learners' writing performance. CALICO Journal, 31(1), 78-102. doi:http://dx.doi.org/10.11139/cj.28.2.345-368

Wu, W. V., Scott, J., Hsieh, C., \& Yang, J. C. (2017). Creating an Online Learning Community in a Flipped Classroom to Enhance EFL Learners 'Oral Proficiency. 20, 142-157.

Yin, R. K. (2017). Designing Case Studies. In Case Study Research and Applications: Design and Methods. 